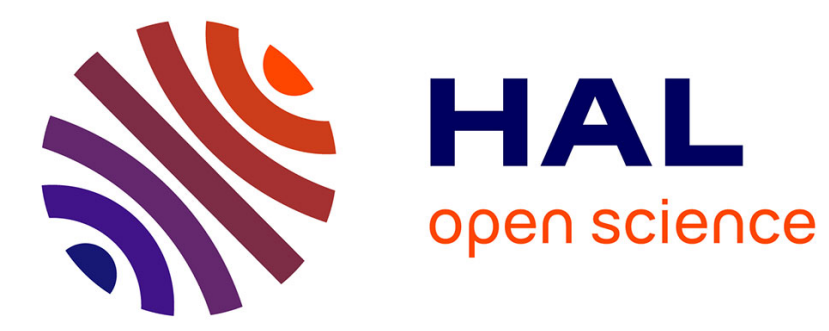

\title{
Proteins involved in Campylobacter jejuni 81-176 recovery after high-pressure treatment.
}

Clemence C. Bieche, Marie de Lamballerie, Michel M. Federighi, Alain Le Bail, Odile Tresse

\section{- To cite this version:}

Clemence C. Bieche, Marie de Lamballerie, Michel M. Federighi, Alain Le Bail, Odile Tresse. Proteins involved in Campylobacter jejuni 81-176 recovery after high-pressure treatment.. Annals of the New York Academy of Sciences, 2010, 1189, pp.133-138. 10.1111/j.1749-6632.2009.05180.x . hal-02664990

\section{HAL Id: hal-02664990 https: / hal.inrae.fr/hal-02664990}

Submitted on 31 May 2020

HAL is a multi-disciplinary open access archive for the deposit and dissemination of scientific research documents, whether they are published or not. The documents may come from teaching and research institutions in France or abroad, or from public or private research centers.
L'archive ouverte pluridisciplinaire HAL, est destinée au dépôt et à la diffusion de documents scientifiques de niveau recherche, publiés ou non, émanant des établissements d'enseignement et de recherche français ou étrangers, des laboratoires publics ou privés. 


\title{
Proteins involved in Campylobacter jejuni 81-176 recovery after high-pressure treatment
}

\author{
Clémence Bièche, ${ }^{1,2}$ Marie de Lamballerie, ${ }^{2}$ Michel Federighi, ${ }^{1}$ Alain Le Bail, ${ }^{2}$ \\ and Odile Tresse ${ }^{1}$ \\ ${ }^{1}$ UMR-INRA 1014 SECALIM ENVN/ENITIAA, Ecole Nationale Vétérinaire de Nantes, Nantes, France. ${ }^{2}$ UMR-CNRS 6144 \\ GEPEA, ENITIAA, Nantes, France
}

Address for correspondence: Dr. Odile Tresse, UMR-INRA 1014 SECALIM ENVN/ENITIAA, Ecole Nationale Vétérinaire de Nantes, Route de Gachet, BP 40706, F-44307 Nantes Cedex 3, France. tresse@vet-nantes.fr

\begin{abstract}
Campylobacteriosis has been recognized as the major bacterial food-borne infection worldwide. Campylobacter, especially $C$. jejuni, contaminate mainly poultry meat. Although more sensitive than other food-borne pathogens to many stresses, $C$. jejuni can survive food processing and go on to reach its final reservoir (the human gut). Genomic analyses of this organism indicate a lack of genes described in other gram-negative bacteria to overcome stresses. The high-pressure recovery response of $C$. jejuni 81-176 was analyzed from two-dimensional electrophoretic profiles of the cytoplasmic proteome. The main cellular mechanisms controlling the down- and upregulated proteins are discussed.
\end{abstract}

Keywords: Campylobacter jejuni; high pressure; recovery; protein synthesis; metabolic pathway

\section{Introduction}

Campylobacter jejuni is the most frequent human food-borne pathogen worldwide. This microorganism is responsible for campylobacteriosis in humans: a disease ranging from a self-limiting gastroenteritis to a more serious systemic infection. In addition, a small proportion of patients, including children, can develop serious complications like neuroparalytic diseases known as Guillain-Barré or Miller-Fisher syndromes. This zoonotic pathogen is transmitted by food of animal origin, especially poultry. ${ }^{1}$ In Europe, the prevalence of campylobacterioses is around 63/100,000, as compared to $52 / 100,000$ for salmonelloses. ${ }^{2}$

However $C$. jejuni appears to be a more fragile organism than other bacterial pathogens (particularly to heat, oxidation, and acidity). ${ }^{3}$ Moreover, this microorganism is unable to grow in the presence of air or at a temperature lower than $30^{\circ} \mathrm{C}$. C. jejuni cannot multiply in food where it endures all environmental stresses, but the great campylobacteriosis incidence indicates its great survival rate. ${ }^{4} \mathrm{On}$ the other hand, genomic analyses of $C$. jejuni have shown a lack of general well-described bacterial resistance gene products, such as RpoS, for stationary phase and the general stress responses, SoxRS and OxyR for the oxidative stress response, $\mathrm{RpoH}$ for the heat shock response, and CspA for the cold shock response. ${ }^{5}$ The absence of DNA repair genes ( $a d a, p h r$, $v s r, m u t H, m u t L$, and $s b c B$ ) and SOS response genes (lexA, umuC, and $u m u D$ ) has also been reported. ${ }^{6}$ This indicates that $C$. jejuni must have unknown resistance mechanisms to respond to environmental stresses.

The effect of high pressure (HP) on C. jejuni has not received much study. This pathogen was shown to be rather sensitive to HP as compared to other food-borne pathogenic bacteria: the bactericidal effect was obtained at $400 \mathrm{MPa}^{7,8}$ Its sensitivity depends on strain, medium (food or broth), and growth phase. ${ }^{9,10}$ The inactivation of the C. jejuni strain EB1410/02 has been modeled as a function of pressure, temperature, and time in poultry meat slurries with a first-order kinetic model. ${ }^{11} \mathrm{An}$ other study comparing C. jejuni strains NCTC 11168 and 81-176 demonstrated that these two strains, which had similar resistances to $\mathrm{HP}$ at $20^{\circ} \mathrm{C}$, had 
different sensitivities to the same pressure treatment performed at $37^{\circ} \mathrm{C}$. The sensitivity of strain 81-176 was not changed with an increase of temperature from $20^{\circ} \mathrm{C}$ to $37^{\circ} \mathrm{C}$ when $\mathrm{HP}$ treatment was performed in a $\mathrm{pH} 7.0$ buffer. ${ }^{12}$ However, the physiological mechanisms involved in C. jejuni HP response are still unknown.

The purpose of this study was to better understand how $C$. jejuni recovers after a sublethal HP treatment by comparing the cytoplasmic proteome of pressurized and unpressurized cells.

\section{Material and methods}

\section{Strain and growth conditions}

C. jejuni 81-176 strain, a particularly virulent strain whose genome has been sequenced, was selected. ${ }^{13}$ It was stored at $-80^{\circ} \mathrm{C}$ in Brain and Heart Infusion (BHI) (Oxoid, Basingstoke Hampshire, UK) supplemented with $15 \%$ glycerol (Nutri-Service, Villefranche-de-Rouergue, France). Prior to each experiment, cells were subcultured onto Karmali agar (Oxoid) for $48 \mathrm{~h}$, then one grown colony was suspended in $50 \mathrm{~mL}$ of $\mathrm{BHI}$ and incubated for $24 \mathrm{~h}$. Cultures were obtained by inoculating $500 \mathrm{~mL}$ of BHI with $5 \mathrm{~mL}$ of the last subculture and incubated for $16 \mathrm{~h}$ under $110 \mathrm{rpm}$ shaking. All subcultures and cultures were grown at $42^{\circ} \mathrm{C}$ in microaerobic atmosphere $\left(5 \% \mathrm{O}_{2}, 10 \% \mathrm{CO}_{2}\right.$, and $85 \%$ $\mathrm{N}_{2}$ ).

\section{Pressurization and recovering conditions}

Stationary phase-cultured cells were harvested by centrifugation at $7000 \times \mathrm{g}$ for $20 \mathrm{~min}$ at $20^{\circ} \mathrm{C}$ and suspended in $500 \mathrm{~mL}$ of phosphate buffer at pH $7.0\left(0.2 \mathrm{~mol} / \mathrm{L}^{-1} \mathrm{Na}_{2} \mathrm{HPO}_{4}\right.$ [Merck, Darmstadt, Germany] and $0.2 \mathrm{~mol} / \mathrm{L}^{-1} \mathrm{NaH}_{2} \mathrm{PO}_{4}$ [Merck]) in sterile polyethylene bags (AES, Combourg, France) which were sealed under sterile conditions.

Pressurization was carried out in a thermostated vessel of a 3.51 reactor unit (ACB Pressure Systems, Nantes, France). In a previous study, it was demonstrated that $C$. jejuni strain $81-176$ started to be inactivated after $200 \mathrm{MPa}$ for $10 \mathrm{~min} \mathrm{HP}$ treatment at either $20^{\circ} \mathrm{C}$ and $37^{\circ} \mathrm{C}^{13}$ Consequently, a pressure treatment of $220 \mathrm{MPa}$ for $10 \mathrm{~min}$ at $37^{\circ} \mathrm{C}$ was applied to the cells: the cell reduction after treatment was less than $0.5 \log (\mathrm{CFU} / \mathrm{mL})$ as calculated from plate counts. The control culture was subjected to the same conditions without HP treatment, that is, $10 \mathrm{~min}$ at $37^{\circ} \mathrm{C}$ under atmospheric pressure. After HP treatment, cells were harvested and suspended in preheated $\mathrm{BHI}$ during $1 \mathrm{~h}$, at $42^{\circ} \mathrm{C}$ under microaerophilic conditions and $110 \mathrm{rpm}$ shaking.

\section{Protein extraction}

Cells were retrieved by centrifugation at $7000 \mathrm{~g}$ for $20 \mathrm{~min}$ and washed consecutively with $200 \mathrm{mM}$ glycine solution (Sigma-Aldrich, Saint-Quentin Fallavier, France) and $100 \mathrm{mM}$ Tris-HCl pH 7.0 solution (Sigma-Aldrich). Pellets were resuspended in $10 \mathrm{~mL}$ of a $10 \mathrm{mM}$ Tris- $\mathrm{HCl} \mathrm{pH} 7.0$ solution and cells were disrupted by series of $6 \times 30 \mathrm{sec}$ sonication with 6-min intervals on ice (Vibracell 72434, Bioblock Scientific, Illkirch, France). To eliminate cell debris, samples were centrifugated twice at $10,000 \mathrm{~g}$ for $20 \mathrm{~min}$ at $4^{\circ} \mathrm{C}$. Then, cytoplasmic proteins were separated from membrane fractions by ultracentrifugation at $188,000 \times g$ for $1 \mathrm{~h}$ at $4^{\circ} \mathrm{C}$. Then, the cytoplasmic protein fraction in the supernatant was treated with protease inhibitor cocktail tablets COMPLETE (Roche Diagnostics, Mannheim, Germany) and nuclease solution with final concentrations of $0.06 \mathrm{mg} / \mathrm{mL}$ RNAse and $0.12 \mathrm{mg} / \mathrm{mL}$ DNAse (Sigma-Aldrich). Protein samples were dialyzed using cellulose membrane tubing with a cutoff at 12,000 Da (Sigma-Aldrich) against MilliQ water at $4^{\circ} \mathrm{C}(800 \mathrm{~mL}$ water for $5 \mathrm{~mL}$ sample) in shaking conditions, during 3 days by refreshing the dialyze bath each day. Purified protein samples were then aliquotted and stored at $-80^{\circ} \mathrm{C}$. Total protein concentration was determined using the Micro BCA Protein Assay Kit (Perbio Science, Brebieres, France).

\section{Two-dimensional gel electrophoresis}

A quantity of $100 \mu \mathrm{g}$ of protein was concentrated using Concentrator 5301 (Eppendorf, Le Pecq, France), at room temperature, to reduce the solution volume to $15 \mu \mathrm{L} \pm 5 \mu \mathrm{L}$. Then, each sample was diluted with $275 \mu \mathrm{L}$ of a $6 \mathrm{~mol} / \mathrm{L}^{-1}$ urea, $2 \mathrm{~mol} / \mathrm{L}^{-1}$ thiourea, $4 \%$ CHAPS, $0.4 \%$ DTT, a few grains of Bromophenol blue (BB) (Sigma-Aldrich) and 2\% Biolyte 3/10 (Bio-Rad, Marnes la Coquette, France) solution. Proteins in the rehydratation solution were absorbed overnight by a $17 \mathrm{~cm} \mathrm{pH} \mathrm{4-7} \mathrm{IPG} \mathrm{strip}$ (Bio-Rad). Then, the Iso-ElectroFocalization (IEF) was performed using the Bio-Rad IEF program as 


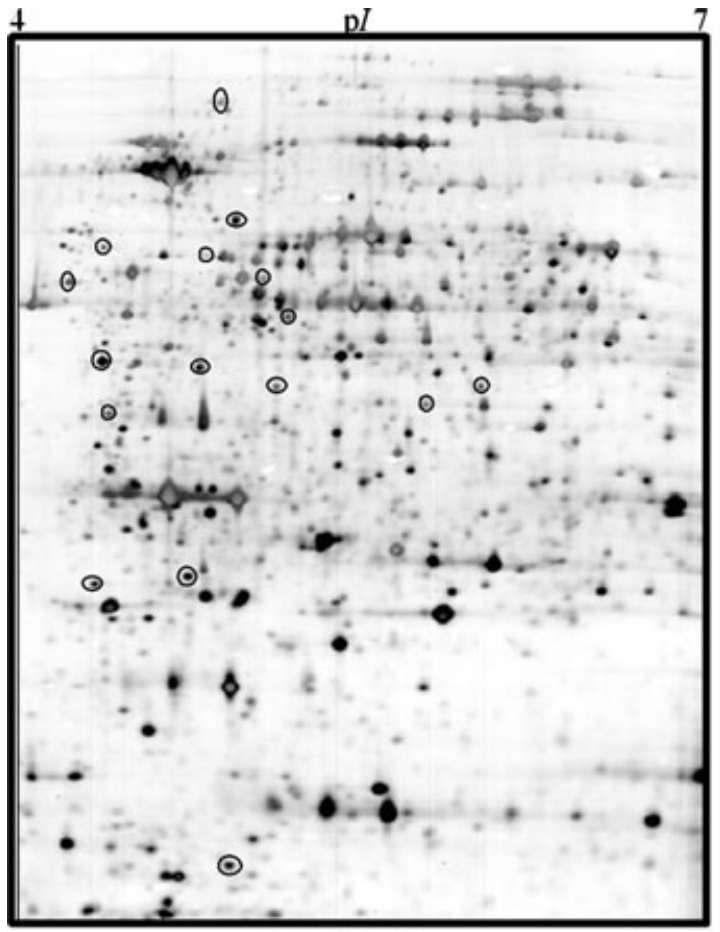

$0.1 \mathrm{MPa}$ (room pressure)

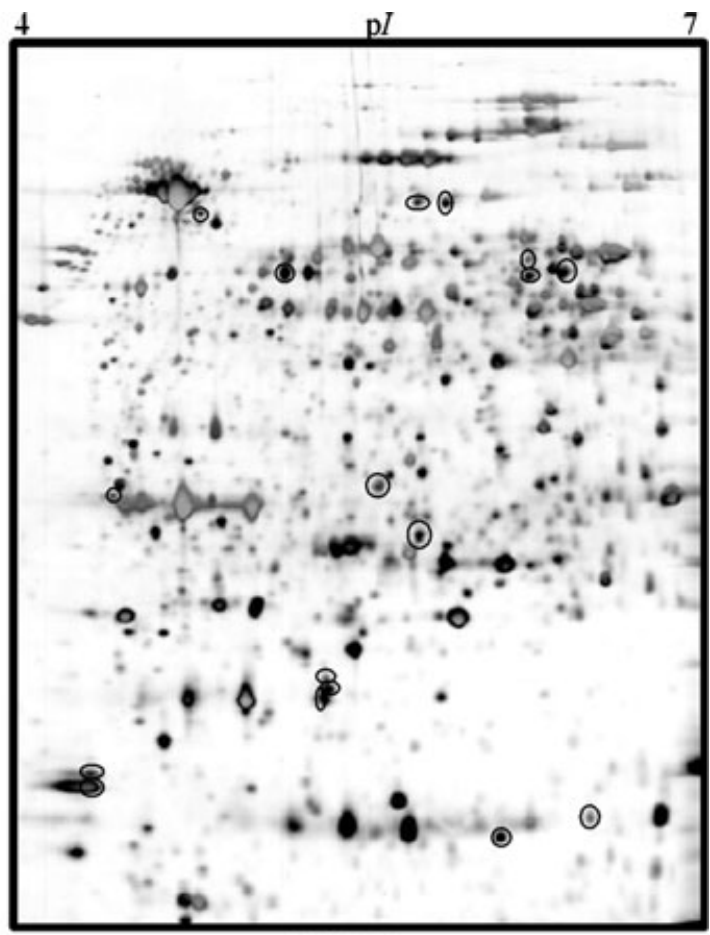

$220 \mathrm{MPa}$

Figure 1. Two-dimensional electrophoresis gels of $C$. jejuni 81-176 obtained after 1 h recovering from HP treatment with 16 repressed proteins $(0.1 \mathrm{MPa}$ gel) and 17 overexpressed proteins (220 MPa gel).

follows: from 50 to $250 \mathrm{~V}$ for $3 \mathrm{~h}$, from 250 to $6000 \mathrm{~V}$ for $3 \mathrm{~h}$, and at $6000 \mathrm{~V}$ until reaching 54,000 Vh. Finally, each strip was soaked for $20 \mathrm{~min}$ in equilibration buffer $\left(1.5 \mathrm{~mL}\right.$ of a $6 \mathrm{~mol} / \mathrm{L}^{-1}$ urea, $2 \%$ SDS, $0.05 \mathrm{~mol} / \mathrm{L}^{-1}$ Tris- $\mathrm{HCl}$ (pH 8.8), 30\% glycerol, and a few grains of BB solution) supplemented with $2 \%$ DTT and subsequently for $20 \mathrm{~min}$ in equilibration buffer with $4 \%$ iodoacetamide (Bio-Rad). The second dimension was performed in $12 \%$ acrylamide gels $(20 \mathrm{~cm} \times 20 \mathrm{~cm} \times 0.1 \mathrm{~cm})$ covered with $1 \%$ low-melting point agarose (Biorad, Hercules, CA, USA) and run at $40 \mathrm{~mA} /$ gel at $14^{\circ} \mathrm{C}$ using a Protean II xi cell (Biorad) until the migration reached the base of the gels. Proteins in gels were finally silver stained and scanned with a GS-800 densitometer (Bio-Rad) operated with the QuantityOne software (Bio-Rad) at the resolution of $42.3 \mu \mathrm{m}$.

\section{Image and statistical analysis}

The image analysis was performed using the Progenesis Samespots software (NonLinear Dynamics, Newcastle upon Tyne, UK). For the statistical analy- sis of the results, two independent experiments were performed, with three technical replicates for each of them.

Differences between the two conditions from the independent experiments and replicates were validated by principal component analysis (PCA) and differences among matched spot intensities were statistically validated by performing an ANOVA (at a $5 \%$ significance level).

When spots of interest were located, twodimensional electrophoresis gels were performed again using $500 \mu \mathrm{g}$ of proteins and were stained with BioSafe colloidal Coomassie blue (Bio-Rad). Visible spots of interest were picked up and the corresponding proteins were analyzed after trypsin digestion by LC-MS/MS (LTQ-Orbitrap Discovery) at the PAPPSO platform of the INRA Center in Jouyen-Josas (France). Resulting peptides were analyzed with Bioworks 3.3.1 SP1 software (Thermo Fisher Scientic, Cergy-Pontoise, France) searched against the draft of the genome of $C$. jejuni sequenced strains. 
Table 1. Metabolic pathways influenced by HP in C. jejuni $81-176$ after $1 \mathrm{~h}$ of recovery

\begin{tabular}{ll}
\hline & Metabolic pathways \\
\hline Repressed after HP recovery & \multicolumn{1}{c}{ Overexpressed after HP recovery } \\
\hline Energy metabolism & Carbohydrate synthesis and energy metabolism \\
Nucleotide metabolism & Fatty acids synthesis \\
Translation & Translation \\
Amino acid metabolism & Amino acid metabolism \\
Metabolisms of cofactors and vitamins & Signal transduction \\
Motility and chemotaxis & Stress responses \\
\hline
\end{tabular}

The functional categories for proteins classification were those used by the Kyoto Encyclopedia of Genes and Genomes. ${ }^{14}$

\section{Results and discussion}

The recovery response of $C$. jejuni after HP treatment was analyzed by comparing electrophoretic profiles of the cytoplasmic proteome of $C$. jejuni 81-176 with or without $220 \mathrm{MPa}$ pressurization. Replicability and reproducibility of the gels were insured by an available dynamic range over $85 \%$ and an available intensity levels over $96 \%$ as calculated by Samespots software (NonLinear Dynamics). The differences between electrophoretic gels obtained from cells with or without HP treatment were validated by the analyses of a PCA plot that groups proteomic profiles with HP treatment on one side and proteomic profiles without treatment on the other side (data not shown). Among the spots significantly different between the two conditions at a $5 \%$ significance level, spots were selected based on a spot intensity variation of at least twofold between the two conditions and variations repeated on at least five of six gels for the same condition. Finally, 33 of these spots were detected on Coomassie blue gels and identified by mass spectrometry. Sixteen proteins were found to be repressed and 17 proteins were overexpressed after HP treatment (Fig. 1). Table 1 represents the metabolic pathways in which the proteins were regulated after HP treatment in $C$. jejuni 81-176.

Repressed proteins were involved in nucleotide metabolism, translation, amino acid metabolism, energy metabolism, metabolisms of cofactors and vitamins, motility, and chemotaxis. Oxygen binding was lowered, which could mean that cells limited oxidative stress caused by oxygen. Since processes, such as motility and chemotaxis, are not critical for survival, their repression could indicate the redirection of energy to recovery processes. The overexpressed proteins during HP recovery were essentially involved in carbohydrate synthesis and energy metabolism, fatty acids synthesis, amino acid metabolism, translation, signal transduction (a Campylobacter-specific two-component regulator), and stress responses. The intensified metabolic pathway indicated that cells needed energy to repair HP injuries; the lipidic portion of cell membranes might be damaged, and the biotin carboxylase overexpression could induce repairs or composition changes in cell-membrane fatty acids; amino acid anabolisms and tRNA synthesis could indicate de novo protein syntheses, while amino acid catabolism (in particular asparate lysis) would allow energy production by the neoglucogenesis pathway. Indeed, C. jejuni does not have a functional glycolytic pathway due to the absence of orthologs of glucokinase and 6phosphofructokinase. ${ }^{7}$ HP stress proteins belonged to general stress and oxidative stress responses.

Compared to L. monocytogenes, E. faecalis, E. faecium, and L. sakei, C. jejuni had a different proteomic profile during HP recovery. ${ }^{15}$ However, some parts of the responses were similar: the evolution of the energy metabolism and carbohydrate transport, the protein synthesis pathway, and the induction of general stress proteins. Among the differences, the induction of cold shock proteins by three of the four Gram-positive bacteria differed from the stress proteins produced by $C$. jejuni, and only L. monocytogenes like C. jejuni expressed oxidative 
stress proteins. A similar comparison was made to the proteomic study of $L$. sanfranciscensis, whose proteomic profile after HP treatment contained significant overlaps with profiles of cold- and $\mathrm{NaCl}-$ stressed cells. ${ }^{16}$ Studies of the response of E. coli to HP showed that there are links between its pressure response and heat shock. Of 55 pressure-induced proteins, 11 were heat shock proteins compared to 4 cold shock proteins and the production of heat shock proteins enhanced E. coli resistance to HP. ${ }^{17,18}$ The resistance of E. coli was largely but not completely related to RpoS activity ${ }^{19}$ and a part of its response to HP was an SOS response, which stabilizes and repairs DNA. ${ }^{20}$ No orthologs to rpoS or to genes associated with the SOS response, such as lexA, $u m u C$, and $u m u D$, were identified in the C. jejuni genome. ${ }^{6}$ Other unknown mechanisms could provide HP resistance in C. jejuni. However, most of the overexpressed proteins detected after HP treatment are not known to play a role in stress resistance. Interestingly, overexpression of oxidative stress proteins involved in the HP recovering response was observed. This is in accordance with the observations of Aertsen et al. on E. coli after HP treatment. ${ }^{21}$ The authors demonstrated that HP treatment induces endogenous intracellular oxidative stress in cells. As a microaerophilic micro-organism, C. jejuni is particularly sensitive to oxidative stress. This would explain why oxidative stress proteins are overexpressed after HP recovering response and also why $C$. jejuni is more sensitive to HP than other Gram-negative bacteria, as mentioned in previous studies. ${ }^{7,8}$

\section{Acknowledgments}

We would like to thank Alain Guillot (INRAPAPPSO) for the protein identifications, Florence Jugiau, Florence Rama (ENVN/INRA-SECALIM), Olivier Rioux (ENITIAA-GPA), and Romuald Chéret (CTCPA) for their technical help and their advice.

\section{Conflicts of interest}

The authors declare no conflicts of interest.

\section{References}

1. Federighi, M. 1999. Campylobacter et hygiène des aliments. Polytechnica. Paris.

2. Fosse, J., H. Seegers \& C. Magras. 2008. Foodborne zoonoses due to meat: a quantitative approach for a comparative risk assessment applied to pig slaughtering in Europe. Vet. Res. 39(1). Epub 2007 Oct 25. PMID: 18073088

3. Butzler, J.P. 2004. Campylobacter, from obscurity to celebrity. Clin. Microbiol. Infect. 10: 868-876.

4. Murphy, C., C. Carroll \& K.N. Jordan. 2006. Environmental survival mechanisms of foodborne pathogen Campylobacter jejuni. J. Appl. Microbiol. 100: 623632.

5. Park, S.F. 2002. The physiology of Campylobacter species and its relevance to their role as foodborne pathogens. Int. J. Food Microbiol. 74: 177-188.

6. Parkhill, J., B.W. Wren, K. Mungall, et al. 2000. The genome sequence of the food-borne pathogen Campylobacter jejuni reveals hypervariable sequences. Nature 403: 665-668.

7. Shigehisa, T., T. Ohmori, A. Saito, et al. 1991. Effects of high hydrostatic pressure on characteristics of pork slurries and inactivation of microorganisms associated with meat and meat products. Int. J. Food Microbiol. 12: 207-216.

8. Solomon, E.B. \& D.G. Hoover. 2004. Inactivation of Campylobacter jejuni by high hydrostatic pressure. Lett. Appl. Microbiol. 38: 505-509.

9. Martinez-Rodriguez, A. \& B.M. Mackey. 2005. Factors affecting the pressure resistance of some Campylobacter species. Lett. Appl. Microbiol. 41: 321-326.

10. Martinez-Rodriguez, A. \& B.M. Mackey. 2005. Physiological changes in Campylobacter jejuni on entry into stationary phase. Int. J. Food Microbiol. 101: 1-8.

11. Lori, S., R. Buckow, D. Knorr, et al. 2007. Predictive model for inactivation of Campylobacter spp. by heat and high hydrostatic pressure. J. Food Prot. 70: 20232029.

12. Bieche, C., M. Ritz, O. Tresse, et al. 2009. Impacts of treatment parameters on the inactivation of Campylobacter jejuni by high pressure: a statistical study of main effects and interactions. Lett. Appl. Microbiol. 48: 198-202.

13. Hofreuter, D., J. Tsai, R.O. Watson, et al. 2006. Unique features of a highly pathogenic Campylobacter jejuni strain. Infect. Immun. 74: 4694-4707.

14. KEGG. Kyoto Encyclopedia of Genes and Genomes. Available from: http://www.genome.jp/kegg/ (accessed in 2008).

15. Jofre, A., M. Champomier-Verges, P. Anglade, et al. 2007. Protein synthesis in lactic acid and pathogenic bacteria during recovery from a high pressure treatment. Res. Microbiol. 158: 512-520.

16. Hörmann, S., C. Scheyhing, J. Behr, et al. 2006. Comparative proteome approach to characterize the high 
pressure stress response of Lactobacillus sanfranciscensis DSM 20451. Proteomics 6: 1878-1885.

17. Welch, T.J., A. Farewell, F.C. Neidhardt, et al. 1993. Stress response of Escherichia coli to elevated hydrostatic pressure. J. Bacteriol. 175: 7170-7177.

18. Aertsen, A., K. Vanoirbeek, P. De Spiegeleer, et al. 2004. Heat shock protein-mediated resistance to high hydrostatic pressure in Escherichia coli. Appl. Environ. Microbiol. 70: 2660-2666.

19. Mackey, B.M. \& P. Manas. 2008. Inactivation of Es- cherichia coli by high pressure. In High-Pressure Microbiology. Michiels, C.W., D.H. Bartlett \& A. Aertsen, Eds.: 53-85. ASM Press. Washington, DC.

20. Aertsen, A., R. Van Houdt, K. Vanoirbeek, et al. 2004. An SOS response induced by high pressure in Escherichia coli. J. Bacteriol. 186: 6133-6141.

21. Aertsen, A., P. De Spiegeleer, K. Vanoirbeek, et al. 2005. Induction of oxidative stress by high hydrostatic pressure in Escherichia coli. Appl. Environ. Microbiol. 71: 22262231. 